\title{
How Do You Make Yourself a Chapter Without Organisation?
}

Phil Gaydon; Conor Heaney; Hollie Mackenzie; Iain MacKenzie

\begin{abstract}
We have no idea yet what a chapter can do.
\end{abstract}
(Spinoza, 2030: 124)

A book of philosophy should be in part a very particular species of detective novel, in part a kind of science fiction. By detective novel we mean that concepts, with their zones of presence, should intervene to resolve local situations. They themselves change along with the problems. They have spheres of influence where, as we shall see, they operate in relation to 'dramas' and by means of a certain 'cruelty'. They must have a coherence among themselves, but that coherence must not come from themselves. They must receive their coherence from elsewhere.

(Deleuze, 1994: $x x$ )

The reading, writing, and concept of a chapter is comprised of a multiplicity of components which machinically function in the ensembles of texts, books, disciplinary apparatuses of knowledge production, and interacting embrained bodies in and through which these components flow. The chapter itself most often functions within the desiring-machine of the book, enabling that 'factor of communication' that Félix Guattari and Gilles Deleuze describe in relation to the function of machines (Guattari and Deleuze, 2009: 92). The chapter has an indissociable relationship to space: the materiality of the text (the chapter as technics) takes up space in the world, it occupies space by transforming raw material elements into a new machine (the chapter, the book). The chapter is also always related to time: not only in the sense of the chapter taking time to conceive of, research, produce, and then to read (those vital elements of any experimental process of knowledge production...), but also in the sense that these components thereby produce a chapter in the life of those involved in its production, and are imprinted in memory (both in the sense of the material memory that the book is (as technics or nonorganic memory support (Stiegler, 1998: 159)) and in the sense of how each "chapter in the life of..." has effects on the level of neurology, consciousness, affect, and so forth. To use Bernard Stiegler's phrase, the production of nonorganic organisations of matter is the pursuit of life by means other than life' (Stiegler, 1998: 17). As such, the production of a chapter is the production of prosthesis and projection, launching itself into the future through the production of new artificial memory supports (Stiegler, 1998: 234).

Furthermore, the chapter is also political, in the sense that chapters form structures of governance, cooperation, and power which together form book-machines or other machinic ensembles of power. Reduced further, the chapter can be broken down into further indispensable components: the rules of language, the rules of the text, the rules of form and content; in short, the rules of sense-making and proper academic practice and exchange. When activated in both the processes of writing and reading, one of the (multiplicitous) machinic functions of the chapter is that of activating a pedagogical process. Not only does writing transform elements of the world (not least, the writer) in the process of writing (itself a process of continuous reading), but reading likewise constitutes a transformative process (the reader transforms the text through reading and the process of reading transforms the reader). These 
multiplicitous transformative functionalities, always unpredictable, open the chapter transversally to function as a node (Guattari, 2009: 146), helping to open up that ever-present potentiality of thinking and being in the world differently. There is a pedagogy of the chapter which is differentially actualised by each reader through reading. Readers do not read in a vacuum. They bring and apply expectations into the practice of reading, as well as embodied positionalities expressive of their singularity. Knowing how and in what sense to approach, evaluate, and judge a text differentiates the reading subject further: is this text "serious" business, requiring "serious" effort, and which will lead to "serious" epistemological dividends? Or is this text flimsy, anarchic, nonsensical; might this text result is an epistemological loss for the reader? Or something else entirely? These questions are, implicitly or explicitly, expressed in the stylistics of reading applied. These differential stylistics ignite the text-reader relation and are further indispensable components in the pedagogy of the chapter which the writer(s) have nothing to do with; this is the singularity of any practice of reading. This indeterminability of the pedagogy of the chapter is vast, always opening the chapter up to the potential of being played with - reading always, to an extent, puts both the reader and the text into play, in which 'the reader is produced as différance, that is, as a reading that is always different, unceasingly to be resumed and deferred as the unceasing itself (Stiegler, 1998: 235) - reading being in this sense inseparable from a play and the constitutive mise-en-scène of the text-reader relation. To read is, at least in part, to make decisions in the absence of determination. As Henri Lefebvre notes:

Even when we are playing, or above all when we are playing, we have to make decisions. To play is to transform our point of view into a decision by confronting chance and determinism in the absence of adequate information about our opponent's game. (Lefebvre, 2014: 39)

This, of course, also applies to writing. A claim, therefore: both writing and reading are indissociable from the element of play; both reading and writing constitute playful practices. All reading, all writing, involves decisions and the transformation of viewpoints in that space of elementary conditionality between "chance" and "determinism." The memory that this text is always in relation to that unknown and improbable future, that incalculable future 'as the opening up of an improbable time: time qua undetermined as game of chance' (Stiegler, 2009: 128). You, dear reader, are playing with us right now.

\section{Didn't you know?}

Perhaps you did. Perhaps you are an informed, willing and active participant in this playful singularity. Well then: bravo, dear reader. If games be the food of your engagement, play on and give us excess of it!

Perhaps you didn't. Perhaps you are a habitual player, literate in but unaware of the negotiations present right now. That's quite alright. Take our hand. We are more than capable of teaching you about what you already know and showing you how to go about doing what you already do. We are also trained in pointing out to you that your previous knowledge of how to interact with texts was little more than complete ignorance. Believe us when we tell you 
this. "Can you tell me in accessible terms please?" we hear you ask. Why, of course, dear reader: that is simplicity itself.

Perhaps you were aware but are reading for reasons that negate playfulness. In this case, would you be so kind as to exchange the epithet "dear" for something else. Do not mistake this for a slight or slur on your character. "Dear" just wasn't meant for you. Indeed, if you are in the business of reading this contribution for serious reasons and have little room for manoeuvre within the rigid boundaries and official guidelines of the practice which necessitated your presence today, then you, rightly, have neither the time nor the inclination to play with us. Perhaps you have been tasked with discerning whether this work is publishable or not or what its value to the wider academic community might be. Whatever the case may be, dear reader, we beseech you to assign yourself some, much more fitting and worthy title.

Do you believe yourself to be worthy of the epithet 'dear', dear reader? If not, should we expunge the word irrevocably from the material text, like Blake when he violently turned on his audience and defaced plate 3 of Jerusalem? ${ }^{1}$

Is the epithet undeserved but still needed? Do you require an Austen-esque, conspiratorial prompting? ${ }^{2}$ Do we need to condescendingly rebuke your gaze in an attempt to retain or regain some sort of power over the words and arguments, our precious prosthesis and projections, that we have sent into your world for metamorphosis?

If it is neither deserved nor needed, then you must be honest with us, dear reader, and enact the necessary violence on our behalf.

\section{For we are impotent.}

Why, then, would you continue reading this chapter?

Dear reader, if you are female, then we apologise for reproducing the same sexist epithet that is often employed in a passive-aggressive way in order to patronise you. Dear reader, if you are male, then, as previously stated, we apologise if we have also addressed you in an inappropriate manner. However, we do not apologise if we have offended you on the basis that the epithet "dear" is usually employed as a feminine sobriquet and therefore does not suit your criteria for masculine titles. If such a case has occurred, then, dear reader, you must now look to your ego and choose from the following two options:

\footnotetext{
${ }^{1}$ If he ever actually used this word or did so in such a rage (McGann, 2002: 80). Regardless, the image is still striking and provocative, is it not?

${ }^{2}$ If she ever actually used "dear reader." Regardless, it is a lovely turn of phrase and sounds so like her, does it not?
} 
*Swipe right to continue, until you find a page you like. Swipe left to stop reading this chapter.*

Option 1: Save Your Bruised Ego!

If your ego has been bruised, then quickly swipe left to stop reading this chapter. Your ego is too fragile to handle this feminine sobriquet, and it doesn't have too! Swipe left now!

\section{Option 2: Celebrate Your Healthy Ego!}

If your ego is still intact because your idea of masculinity is not so regimented in patriarchal conventions, then hurrah! You are welcome to continue reading this chapter. Swipe right now! 
Welcome back! We're so glad we have created a moment in which you can check your male privilege. So, if you are a male reader and are not offended if you are addressed as "dear," then we have just succeeded in subverting the idea of how a male ought to be addressed. Play enables us the freedom to toy with patriarchal power dynamics and subvert such patriarchal conventions, and subvert them we have!

However, if you are other, dear reader, then please forgive us for our binary modes of thought, for we do not know how to think difference. Let us instead congratulate you on becoming other, what a wonderful state to be becoming. Let us play together; maybe we could join you in your wonderful state. Indeed we are impotent, but we are open to a playful encounter as it contains the possibility to create ruptures within thought that can incite new and different ways of thinking. There is no power here to play with, unless you, dear reader, encounter us. Let us invite you to contribute to this encounter through a simple, but playful, task.

Given the aforementioned problems concerning the title we've given you, dear reader, we will now invite you to select or create your own title that you can input throughout the rest of this chapter. If you opt to create your own title, we entrust that you create one that does not adhere to sexist, racist, or homophobic epithets. We also advise you to be honest with your politics of location and, if you are in a position of power or privilege, to select or create a title that can subvert and problematise your position of power and privilege. Or, if you are in a minority position, then select or create a title that you would feel empowered reading. It's time to play with the power dynamics. Have a look at the examples we've provided in the list, one might be just what you're looking for, or they might spark an idea for a new title:

1. [swift-skimming] reader

2. [mindful $]$ reader

3. [revolutionary] reader

4. [post-] reader

5. [cynical] reader

6. [THE $]$ reader

7. [smooth] reader

Or, we can even erase the noun "reader" to create a whole new title:

8. [Breaker of Books]

9. [Participator of Playful Pedagogy]

10. [Egghead]

Or, create your own title in the box provided:

11. [

Or, please feel free to enact the necessary violence and leave the box (and boxes to follow)

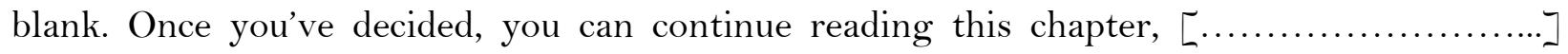
reader, by writing your new title in the blank boxes as you go along, or not writing in them. The full effectiveness of this chapter can only be determined by the interaction made with it. That being said, are you going to get serious about play, or not? 
It is, after all, a matter of potency.

Or, better still, a matter of potentialisation; the processes through which the potential of a body can be engendered. In this case, there are several bodies. There is the body of the text, both its literal physicality and its literal but non-physical organisation, the bodies of the authors, both their biological make-up and their "cultural construction" (such a tired old phrase), the bodies of knowledge informing what we think we should do, both those norms of academic behaviour and those norms of playfulness that take all the fun out it. And more and other bodies - yours, $[\ldots \ldots \ldots \ldots \ldots \ldots \ldots . \ldots . \ldots . \ldots$ reader.

There is, in principle, an infinite series of playful bodily connections that can be engendered within a chapter. Of course, every chapter also has an organisation that limits this series, these connections; not least in an academic chapter governed by rules of coherence, acceptability, consistency, tone and voice, and...a finite order of how these components will be governed for sense to be maintained. What must be found, therefore, are the moments when the organisation of the chapter meets the disorganised serial functioning within its own operations of governance. This is not an easy task for we do not yet know what a chapter a can do. And in order to find out what we can do with a chapter we need a program; a political program that unpicks the ordering of the chapter; that ties it down, stitches it up and whips it senseless (the masochist, as Deleuze and Guattari suggest, being one of those who delineates a program for the body that draws it near to its disorganisation). Such a program is revolutionary, except when revolutionary is defined by some pre-established end, goal, or utopian fixation. It is revolutionary if it encircles the chapter with limits to your interaction with it, limits that then show just how creative one can be when connecting the components together. Have you played the game? It doesn't matter, you can play in whatever manner you like, find whatever bit of this chapter can sting like a whip and desire more of it. In that way, you will revolutionise your reading. Tie us up in consistent and tight problems; you will have found your limits and your revolutionary desire. Connect the pieces of this chapter in ways you did not think possible: you will have found that to create is to resist. It is all a matter of bodily potency, of the potential for forms of bodily interaction that will have us tied in the most beautiful knots and that will unleash your desire for revolutionary transformation. It has nothing to do with sadism, that much is clear. There is nothing revolutionary in the desire to inflict pain. The revolution in the production and consumption of chapters can only be a matter of practical, pragmatic experimentation at the limits of what is possible in a contract between us and you, $[\ldots \ldots \ldots \ldots \ldots \ldots \ldots \ldots . \cdots \cdots \cdot$ reader. It is always a matter of pedagogy, of the learning that provides the "true condition of critique" because it is always the process of unravelling what is known in a playful experimentation and deadly serious pragmatics of sensing what we do not yet know. Our contract, as authors and as author-readers and as author-editors and..., is a pedagogical contract.

Of course, the contract itself is often thought to be a quasi-juridical function of the edited collection. To the extent that it is, it is only a contract that reminds us of one of those other bodies involved in this chapter, in this book; the body of laws that govern what counts as academic production and legitimate scholarship. This quasi-juridical contract is a highly organised body that has lost touch with its intrinsic disorganisation. To get back in touch with this disorganisation the chapter must operate at the limit of the law, the limit where knowledge and power function to bind but also to unbind the political economy of the book. Try putting us down - put the book down and put us in a position of subordination - it is likely to feel good, and you will have found a way of operating on a line that you didn't think you could or should follow. The economies, of desire and production and consumption, will be found and things will start to happen, because every chapter has the sense that it will break out on its own. Every 
chapter of the church, or the Hell's Angels, has enough autonomy to break away, if it can put down the rulebook determining how it should be organised. But, at this point, doesn't it stop being a chapter?

It is a matter of relationality. The contract establishes relations for sure, and the quasijuridical contract establishes these hierarchically so as to maintain ordered forms of governance. But the relation of each chapter to the whole (of the book) always has the potential to become something other than a merely legal entity. Not as a process of opposition for if we stand against the book we will simply leave the order and find ourselves on a line heading towards destruction: 'it is not enough to set up an abstract opposition between the strata and the BwO' (Guattari and Deleuze, 1987: 162). Rather, the revolutionary potential of the contract is the point at which the juridical components cease to function as a whole, so that it becomes a way of (dis)organising differently. It is therefore still a chapter, a part that stands apart from the whole as symptom of the movement within the book; pointing to and expressing the disorganised body that makes every form of organised collection possible. This is why it is a matter of relationality. What kind of relations are possible within a chapter, between the chapter and the whole (book), between the book and the world? What new relations can fracture the quasi-judicial functioning of the contract, in order to release its and your masochistic potential?

1. It is certainly but not only those relations that function within the logic of syntax that can express the outside that resides within the legal order of the chapter.

2. Of those that function, it is only relations within the legal order, the syntax of logic, that can express the outside that resides within the chapter.

3. Only the orders of logic that function outside the chapter, within the legal order of relations, can reside within.

4. Order syntax within the chapter to find the legal certainty within its relations and the outside that resides in logic.

Make language an exquisite corpse and make a chapter that potentialises its disorganisation. Make your own disorganised chapter.

As Deleuze and Guattari say, 'Something will happen. Something is already happening. But what comes to pass on the $\mathrm{BwO}$ is not exactly the same as how you make yourself one. However, one is included in the other' (Guattari and Deleuze, 1987: 152). What comes to pass on the chapter without organisation $(\mathrm{CwO})$ is not exactly the same as how you will make yourself one. It must be this because we 'never knows in advance how someone will learn' (Deleuze, 1994: 165). It is a task of finding your own learning contract if one ever wants to depose those learning contracts that symbolise the educative governance of our bodies of knowledge, of our bodies, of the whole political economy of chapter production and consumption. We will never find ourselves after the contract, but we can find our own forms of (masochistic) contract; those that will engender the specification of what it is that we want to learn, how we want to be tied and twisted, whipped and beaten. Try it, it is playful and it is fun. For sure, there isn't anything that Google doesn't know but it only knows what it knows in one way. Find the algorithms and turn them into knotty problems, make them work against each other and flay them until they bleed. Then the program that will unravel the snake's coils of control society will be found, a revolutionary program of learning outcomes without end.

But isn't this the impotency of potency? Isn't this the moment when all play becomes subsumed within the dead hand of the market? Can we imagine playfulness and a learning 
contract that doesn't come back to us in citations, royalties, recognition, CV building, job applications and promotion? Swipe left?

How cruel this theatre of theory is! For what contract is not cruel? What market, game, or play is not a theatre? Or perhaps the greatest cruelty of all is that it can never be theatrical enough; that our disorganised pursuit of disorganisation remains lifeless to your eyes; immediately usurped and captured; that we could never ignite the sparks of dream and imagination that could electrify our relationship to you, our imagined cruel reader. How could the chapter ever, really, embrace the sort of play, violence, desire, and theatre of which we dream? Too much light would wake us up from this beautiful dream: 'Were it not for shadows, there would be no beauty' (Tanizaki, 2001: 46). The chapter: a light-bearer of reason? We hope you are being cruel amidst this mise-en-scène. Are you being violent enough with the strata? Keep that whip at the ready.

Zarathustra told us to look for that cloud of earthly joy in your eyes, indicating that you are not yet world-weary. Do people still whisper to each other in dark streets that learning is only possible with the relinquishment of violent desire? If so, these world-weary types have relinquished their whips. If that earthly joy is in your eyes, then the chapter might really become a site of cruel and joyful play between us. The $\mathrm{CwO}$ is but a component of passage, with $n$ disarticulations, forever moving in the joyous, cruel, and playful dream-theatre that the book can be. Cruel reader, you know as well as we do that this is no lament, but a joyous expression of how much we have yet to learn! How much more we have to dream...

DISSOLVE TO:

\section{THEORY DREAM-THEATRE INT. RED-DRAPED ROOM}

HOLLIE and the DEARS sit crossed legged and still in a circle, talking inaudibly. The draped room is shrouded in darkness. Dance of the Dream Man by Angelo Badalamenti plays, seeping into the air; a rhythmic motif that remains throughout. Their voices emerge.

\section{HOLLIE}

(intensely)

......Brékkek Kékkek Kékkek Kékkek! Kóax Kóax Kóax! They

would know what's up if they heard that.

\section{DEAR ONE}

(feigning dismay)

I simply cannot agree. To mimic Pausanias's retort to Phaedrus:

if learning had a single nature, that would all be perfectly sensible. But it does not. 
There are at least two types of learning. Technical learning: which transforms the world as it is initially experienced into one of affordances; in which we move from an experience of chaos to an experience of equipment, acquiring savoir-faire. There are specific ways to use equipment. And as such, there are specific ways to learn.

Then noētic learning: the cultivation and taking care of the rational soul; learning how to think; learning towards wisdom......

\section{DEAR TWO} (interrupting DEAR ONE)

Oh, cease your idiotic spew. We've all either read Plato, or chosen not to read him. Just when did you figure out how to think? Who taught you? Or should I say: who deposited this epistemic content in you, like the little piggy you are? And how did you absorb this wisdom anyway? Do you expect our dear, cruel reader to take you seriously for a second?

\section{DEAR THREE}

(leaning back, looking like they have something of key relevance to impart)

You know, in around four billion years, the Milky Way and Andromeda Galaxies will collide, producing a vast spectacle of dancing stars, like a murmuration of starlings: how much chaos, how many dancing stars! Zarathustra would fold [pli] a million times in joy!

(confidently awaits response, the room remains silent aside from the music)

The music intensifies. They continue to exchange words in the darkness. Their voices become clearer again.

\section{DEAR TWO}

Just tell me this: what exactly are we hoping to achieve with this? It all feels rather indulgent. Not only that: unhelpful. What are we even trying to prove?

DEAR THREE grunts whilst wiggling a pinched thumb and finger in their ear with motions akin to tuning a radio. They finally pull out some unidentifiable mass composed of biological and technological material. 


\section{DEAR THREE}

Finally! What an ordeal that was. Am I right?

The others blankly stare.

Fine. Be like that. Hell is other people anyway. Unless you're swiping right. Yes?

The others continue blank stares.

\section{DEAR THREE}

Oh, come on! It's an academic's prerogative, nay, duty, to at least try and procrastinate on this point, wouldn't you agree?

The others offer further blank stares for an awkwardly long time.

\section{DEAR THREE}

\section{Right.}

(Note for director: wherever parentheses appear to suggest an alternative sentiment you may choose what you want to direct the character to speak, or hand over the choice to them)

\section{DEAR THREE}

Indulgent? Yes, I suppose it is. But I never agreed to anything else. Why would I choose to do something if I couldn't indulge a little? And if I can get away with indulging a lot then of course I will do so. Since you are listening to this I suppose I'm getting away with it. Unhelpful? Undoubtedly. If by 'unhelpful' you mean 'made life more difficult'.

Do you suppose that contributing any differently (standardly) would have been any less indulgent? The beautiful writer indulges in their (un)lucky fate. They are disposed to pleasure within and conformity to the rules of the current, dominant game.

The sublime writer strives for a place in the game, exercising their (free) will to conform via impressive feats of sustained selfgovernance so that they might indulge in the ever-present desire

for appreciation. I, however, am neither truly beautiful or sublime. 


$$
\text { (self-pitying sigh) }
$$

I can only offer the occasional graceful pirouette and I have a severely limited amount of will that I can dedicate to my academic conscience. As such, my indulgences do tend towards the grotesque or, at best, uncanny.

Do you suppose the usual contributions to be any less unhelpful? The infinite complexity of specialisation and the perpetuation of strict rules within a publishing game masquerading as necessary see to it that they aren't. The claim to knowledge and, what is worse, maintaining that we can write and create in a way that elucidates anything more than a spectral apparition for flimsily conjoined consideration seems to me to be a myth desperately in need of repeated debunking. If not completely then enough so that these two have their privileges as the grand overseers and gatekeepers of worthy epistemic processes revoked. It is their tyranny that makes life more difficult than anything else I have encountered.

DEAR THREE stops as if interrupted and offers an aghast look but no sound is heard.

\section{DEAR THREE An ultracrepidarian... (flirtatious, self-assured wink to audience)} ... am I? Let me remind you that we "clever beasts invented knowing" and that "there is nothing so reprehensible and unimportant in nature that it would not immediately swell up like a balloon at the slightest puff of this power of knowing." However, I sought to prove very little. I attempted to achieve nothing but creation. I did not try to enforce clarity where there is none. I did not seek to convince you of a position with logic. I did not want to make you see.

For what use is there in that? To synthesise some equine and grandmotherly wisdom I encountered in my (second) youth: "I have heard men say that seeing is believing; but seeing is not believing - it is only seeing. I should say that feeling is believing; for much as I had seen before, I never knew until now."

I do hope however. I hope that engagement is occurring, stimulation happening and meanings are being made. I hope that you have gained by my indulgences and by indulging me. I hope 
that after this tempestuous reading encounter you can appreciate once invisible game-lines. And I hope that just as I have indulged in extending my playful being to these pages so you will go on to do the same elsewhere.

DEAR THREE goes to sit but stops and gets back up.

\section{DEAR THREE}

A brief warning. As a (fictional) teenager once warned a classmate after he killed him for nihilistic transgressions: "the meaning is not something you mess around with.”

Being playful undermines meaning and if you desire an escape from this potentially dangerous territory I offer a reinterpretation of the words of a trusted (but make-believe) coconspirator: "But remember always, this is all an academic text, and only serious business and honesty, and you are to believe every word of it, even if it is false."

During DEAR THREE's monologue, HOLLIE has been examining the unidentifiable mass that DEAR THREE pulled out of their ear. After looking intensely at the forgotten mass on the floor, looks up at DEAR THREE with a concerned and bewildered look.

\section{HOLLIE}

...... what a strange mixture that came out of your ear! No wonder you were speaking nonsense about chaos and dancing stars! What a joyful encounter to have experienced in thought, a painful one too. I can see why you couldn't endure anymore of it.

HOLLIE returns her gaze to the mass on the floor, now a melting pile of biological and technological materials, and starts to poke and pick at the different textures, much to the dismay of the others.

\section{HOLLIE}

Oh don't mind me, I'm just playing with what's come out of your

head. Call it indulgent if you will, but don't you find that working with undesirable or disapproving materials can often yield creative effects? Just look at the affect this mass has had already by inciting the sublime idea of the dancing stars! Oh how thought can travel! Woe to how much we limit how thought

$$
\text { travels... }
$$


With both hands fully submerged in the mass now, HOLLIE brings a handful up to show to the others.

\section{HOLLIE}

Look! Look at this! See how it is transforming... It has stopped the stars from dancing. The joyful thought-event is no longer; it

has become static, fixed. The material has turned to stone. It hurts to even hold it. It has turned into dogmatic knowledge

now...

HOLLIE opens her hand to reveal a stone. She turns her hand to release the stone from her grip; it falls back into the mass on the floor, spraying the others with the rest of the melted mass.

\section{HOLLIE}

Aha! But that is it! You saw nothing! This mass was not pulled out of one person's head to be worshipped for the knowledge it holds and gawked at whilst it turns into stone and cements itself in the minds of others. Indeed, seeing is not believing. To experience the stars dance, you must feel it.

What we are working with here is the invisible chaos that can only be sensed. This is what some dead old white men called the 'iridescent chaos.' Don't recoil to the safety of sight, of truths, to a dogmatic knowledge, to the worshipping of one person's mass. Let us not sit here and spoon-feed each other this mass. For that is when we turn into stone!

Now we can understand why you had to pull it out of your head, dear, a few moments longer all you would have to think is a black hole! What a schizophrenic nightmare! For this sublime mixture is a thought-event that has been concocted by the multiple, to think it is to force thought to travel in multiple directions. Indeed, it is an ordeal, but one that we can all experiment in.

HOLLIE has both of her hands fully submerged in the mass again. DEARS ONE, TWO and THREE are examining the specks of mass that landed on them from the spray. HOLLIE looks across at DEARS ONE, TWO and THREE to beckon them to join her at the melted pile on the floor. 
*Swipe right to continue, until you find a page you like. Swipe left to stop reading this chapter.*

\section{HOLLIE}

As much as this is a melting mass of undesirable and disapproving materials, it is these masses that often make up our shocking and jarring experiences of the world. A way to

\section{think about these}

masses is that

they are

really

only

materials

and tools with

which to play with

to create new and

different, more

joyful, exper-

iences.

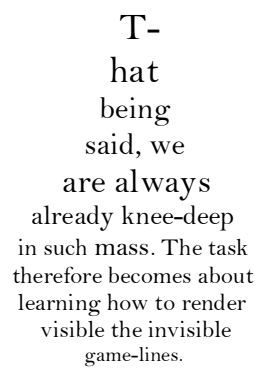

come

on, roll

your sleeves

up and plunge

your hands into

the mass, and feel

the stars dance a-

round them! It's

your turn to draw

your own game-

lines... 
PULL BACK as the music once again intensifies and the room darkens as HOLLIE AND THE DEARS seep into and experiment further with the materials.

FADE TO BLACK.

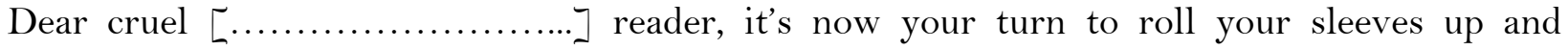
participate with us. Using your hands, render visible the lines on this page by folding the paper. How many times can Zarathustra fold over? How many stars can you feel dancing? How much chaos is there on this page?

Begin folding here:

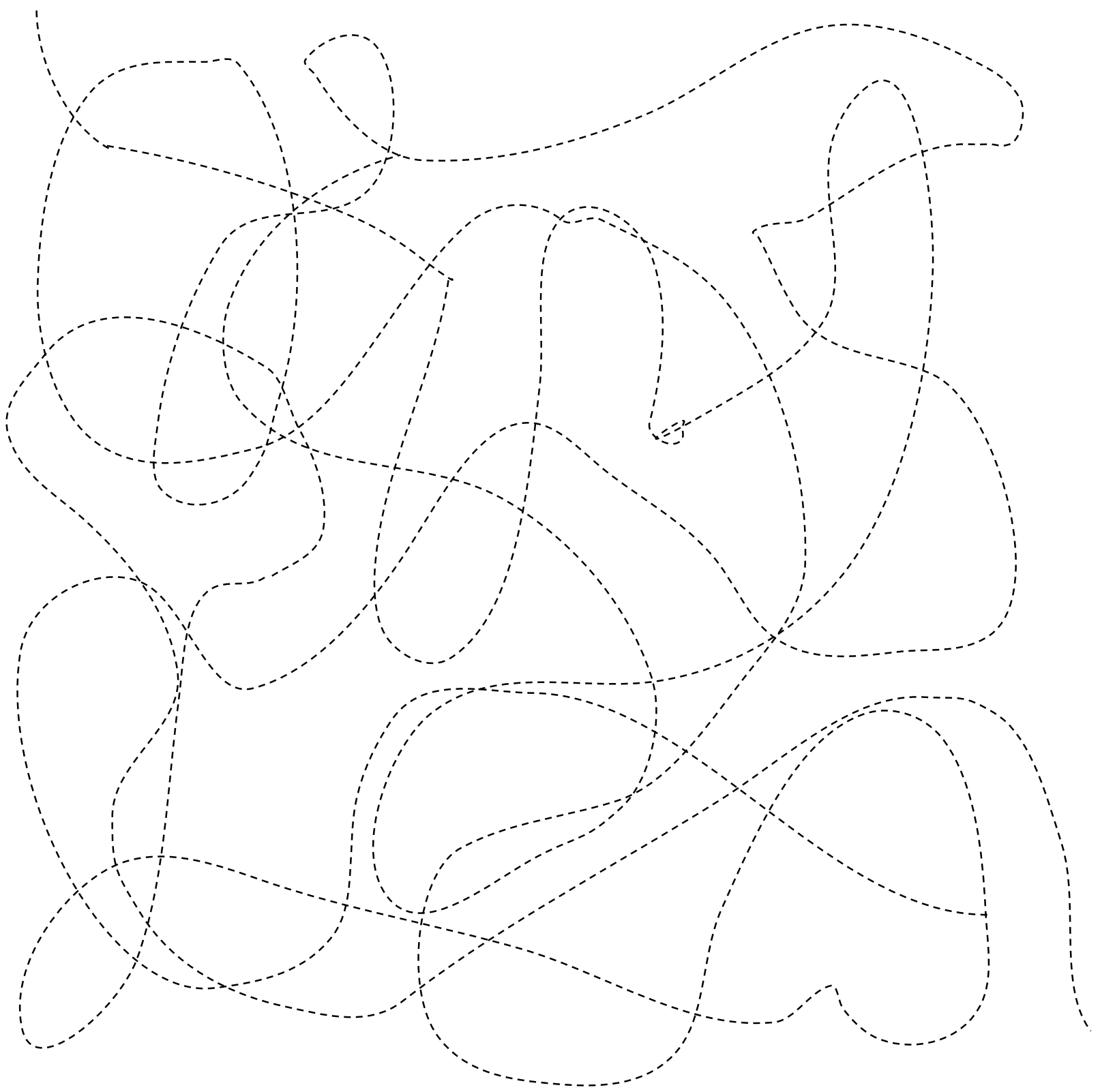


The pedagogy of the chapter with which we began, requires learning how to fold. And how to unfold, because folding and unfolding are not opposed. It is never a matter of the part and the whole, the chapter and the book, but of the movement of folds within folds. It is always a matter of the infinite plane of composition and how to use it. Fold this chapter in on itself and learn how to make yourself a chapter without organisation; after all, no one ever learned anything by being taught.

\section{References}

\section{Bibliography}

Aristophanes, The Frogs and Other Plays, trans. by David Barrett (London: Penguin Classics, 2007)

Cézanne, Paul, Conversations avec Paul Cézanne (Paris: Macula, 1978)

Deleuze, Gilles, Difference and Repetition, trans. by Paul Patton (London: Continuum, 1994)

Guattari, Félix, 'The Best Capitalist Drug', in Chaosophy: Texts and Interviews 1972-1977, ed. by Sylvère Lotringer, trans. by David L. Sweet, Jarred Becker, and Taylor Adkins (South Pasadena: Semiotext(e), 2009), pp. 141-153

Guattari, Félix, and Deleuze, Gilles, 'Balance-Sheet for "Desiring-Machines”, in Guattari, Félix, Chaosophy: Texts and Interviews 1972-1977, ed. by Sylvère Lotringer, trans. by David L. Sweet, Jarred Becker, and Taylor Adkins (South Pasadena: Semiotext(e), 2009), pp. 90-1 15

Guattari, Félix, and Deleuze, Gilles, A Thousand Plateaus: Capitalism and Schizophrenia, trans. by Brian Massumi (Minnesota: University of Minnesota Press, 1987)

Joyce, James, Finnegans Wake (London: Penguin Books, 1992)

Kingsely, Charles, The Water Babies (London: Wordsworth Editions, 1994)

Lefebvre, Henri, 'Critique of Everyday Life, Volume I: Introduction', trans. by John Moore, in Critique of Everyday Life: The One Volume Edition (London: Verso, 2014), pp. 1-272

MacDonald, George, The Princess and the Goblin (London: Wordsworth Editions, 2013)

McGann, Jerome, Byron and Romanticism (Cambridge: Cambridge University Press, 2002)

Nietzsche, Friedrich, 'FROM: On Truth and Lie in an Extra-Moral Sense', in The Portable Nietzsche, ed. and trans. by Walter Kaufman (London: Penguin Books, 1976), pp. 42-50 
Nietzsche, Friedrich, Thus Spoke Zarathustra: A Book for Everyone and No One, trans. by R. J. Hollingdale (London: Penguin Books, 2003)

Plato, The Symposium, trans. by Walter Hamilton (London: Penguin Books, 195 1)

Sewell, Anna, Black Beauty (London: Puffin Books, 2008)

Stiegler, Bernard, Technics and Time, 1: The Fault of Epimetheus, trans. by Richard Beardsworth and George Collins (Stanford: Stanford University Press, 1998)

Stiegler, Bernard, Technics and Time, 2: Disorientation, trans. by Stephen Barker (Stanford: Stanford University Press, 2009)

Tanizaki, Jun'ichirō, In Praise of Shadows, trans. By Thomas J. Harper and Edward G. Seidensticker (London: Vintage Books, 2001)

Teller, Jane, Nothing (New York: Atheneum Books for Young Readers, 2000)

\section{Filmography}

'Episode 2: Zen, or the Skill to Catch a Killer', Twin Peaks. Director: David Lynch, [1990] (DVD, Universal Pictures, 2002) 